\title{
Electrical burns: Highlights from a 5-year retrospective analysis
}

\author{
Alper Kurt, M.D., ${ }^{1}$ Kamil Yıldırım, M.D., ${ }^{1}$ Çağlayan Yağmur, M.D., ${ }^{3}$ Osman Kelahmetoğlu, M.D., ${ }^{2}$ \\ Ozan Aslan, M.D., ${ }^{1}$ Murat Gümüş, M.D., ${ }^{1}$ Ethem Güneren, M.D., ${ }^{2}$
}

\begin{abstract}
1Department of Plastic Reconstructive and Aesthetic Surgery, Samsun Training and Research Hospital, Samsun-Turkey 2Department of Plastic Reconstructive and Aesthetic Surgery, Bezm-i Alem Vakif Foundation University Faculty of Medicine, Istanbul-Turkey ${ }^{3}$ Department of Plastic Reconstructive and Aesthetic Surgery, Ondokuz Mayıs University Faculty of Medicine, Samsun-Turkey
\end{abstract}

\begin{abstract}
BACKGROUND: Electrical burns are the third most common cause of burn injuries, after scald and flame burns. In spite of decreasing mortality rates as advancements are made in treatment modalities and medical equipment, significant complications and socioeconomic consequences still accompany electrical burns. Analyzed in the present study were data from patients hospitalized for electrical burns between 2008 and 2012 in the Samsun Training and Research Hospital, the only burn care center in the Black Sea region of Turkey.

METHODS: Data from 94 patients (84 males, 10 females) hospitalized for electrical burns between 2008 and 2012 were retrospectively evaluated. Patient age, gender, occupation, presence of coexisting trauma, burn degree, burned percentage of total body surface area (TBSA), voltage of the electric current (low or high), medical cost (per day and total), and infection rates were analyzed.

RESULTS: Mean patient age was $26.4 \pm 13.2$ years. Ten patients were female (10.6\%) and 84 were male (89.4\%). High-voltage burns were sustained by 47 patients (50\%) and low-voltage burns by 42 (44.7\%); the remaining 5 were flash burns. Mean burned TBSA was $21.8 \pm 19.8 \%$ in high-voltage injuries and $11.9 \pm 6.9 \%$ in low-voltage injuries. Seven patients had accompanying soft tissue lacerations, major bone fractures, or epidural hematomas. Findings of infection were encountered in 31 patients (32.9\%), and appropriate treatments were initiated according to culture results. Mean duration of hospitalization was $21.3 \pm 19.8$ days in patients with high-voltage burns and $8.6 \pm 6.2$ days in patients with low-voltage burns. Mean hospital stay was 2.5 -fold longer, and total medical costs were 4 -fold higher in patients with high-voltage burns.
\end{abstract}

CONCLUSION: Young adult males who were injured in industrial accidents constituted the majority of high-voltage burn patients. Incidence of these injuries may be reduced by improvements in training regarding the safe use of electrical devices, and correct installation and safe maintenance of power grids, as well as by a review of occupational safety regulations.

Keywords: Electrical burns; retrospective analysis.

\section{INTRODUCTION}

Electrical injuries are the third most common cause of burns after scald and flame burns. In spite of advances in treatment modalities and the resulting decrease in mortality rates, electrical burns may lead to socioeconomic burden, as well as

Address for correspondence: Çağlayan Yağmur, M.D.

Ondokuz Mayıs Üniversitesi Tıp Fakültesi, Plastik Rekonstrüktif ve Estetik Cerrahi Anabilim Dalı, Samsun, Turkey

Tel: +90 363 - 3121919 E-mail: caglayanyagmur@gmail.com

Qucik Response Code Ulus Travma Acil Cerrahi Derg

2016:22(3):278-282
doi: 10.5505/tjtes.20I5.5549।

Copyright 2016

TJTES significant functional and cosmetic problems. ${ }^{[1-5]}$ An electric current can reach deep tissues, and cause deep and extensive injuries. Depending on voltage magnitude, injury may be sustained in nerve, bone, and tendon tissue, as well as that of the skin. ${ }^{[3,6-8]}$ The primary mechanism of tissue injury is the direct effect of the electric current. However, electrical injury can arise from both thermal and non-thermal mechanisms, and other injuries can accompany electrical burns. Tissue injury is determined by the magnitude of the electric current, the duration of exposure, and by tissue resistance. Electrical burns are traditionally classified as high-voltage (>1000V) or low-voltage $(<1000 \mathrm{~V}) \cdot{ }^{[1,9]}$ Flash arc and lightning burns remain outside the traditional classification scheme, and are usually considered high-voltage burns.

These injuries are most prevalent in young adult males, and cause loss of working hours. ${ }^{[1,3,6,7,10]}$ Importantly, these injuries 
can be avoided with proper education, safety regulations, and a safe, effective electricity delivery network.

The aim of the present study was to retrospectively analyze cases of electrical injury treated within a 5-year period at the Samsun Training and Research Hospital, the only burn care center in the Black Sea region of Turkey.

\section{MATERIALS AND METHODS}

Data from patients admitted to the center for electrical burn injuries between 2008 and 2012 were retrospectively analyzed. All patients were admitted upon sustaining the injury, though those referred from other centers were also included.

Burn degree and total body surface area (TBSA) were assessed prior to admission. Each patient was examined for cardiac rhythm and renal function (fluid intake/output, myoglobinuria, blood urea nitrogen, and serum creatinine levels). Accompanying trauma or coexisting disease were also evaluated during initial management. Proper fluid resuscitation was administered according to the Parkland formula (via 2 venous routes in patients with burned TBSA $<30 \%$, and via central venous line in patients with burned TBSA $>30 \%$; an arterial line was provided to monitor need for endotracheal intubation). Urine output of $>30 \mathrm{cc} /$ hour indicated sufficient fluid replacement. Relevant cultures were obtained, and intravenous antibiotics were empirically initiated when signs of infection (hypotension, hypo- or hyperglycemia, alterations in mental state, or fever) were observed. Non-steroidal antiinflammatory drugs were orally or intravenously administered for routine pain relief, and opioids were used as second-line drugs. Wound dressing changes were made daily. Wound debridement, tangential excision, and grafting were performed when necessary. Patients were closely observed for signs of compartment syndrome, and escharotomy or fasciotomy was performed as needed.

Demographics, length of hospital stay, injury mechanism, accompanying trauma, coexisting illnesses, voltage classification of the exposed electrical current (low or high), site of inlet and outlet current, burned TBSA, culture results of burn wounds, surgical interventions, and medical costs per patient were evaluated.

\section{RESULTS}

Data from 94 patients (84 males and 10 females) were evaluated retrospectively. Patient age ranged from 47 months to 72 years. Mean age was $18.8 \pm 8.7$ years for female patients and $27.4 \pm 12.8$ years for male patients. Age and gender data are shown in Figure 1 .

Causes of electrical injuries were industrial accidents $(n=47)$, contact with unattended open electrical wires $(n=21)$, accidents related to climbing utility poles $(n=13)$, lightning $(n=4)$,

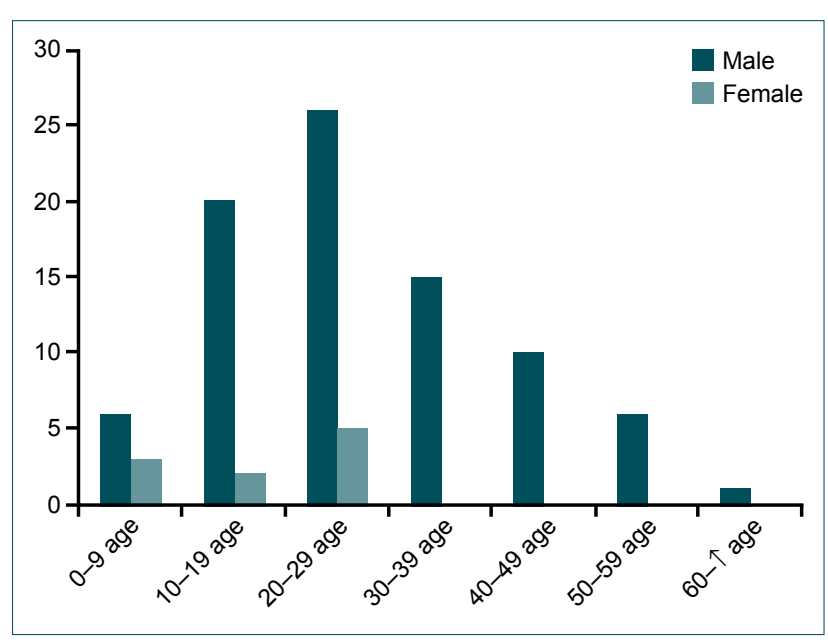

Figure 1. Gender and age distribution of patients with electrical burns.

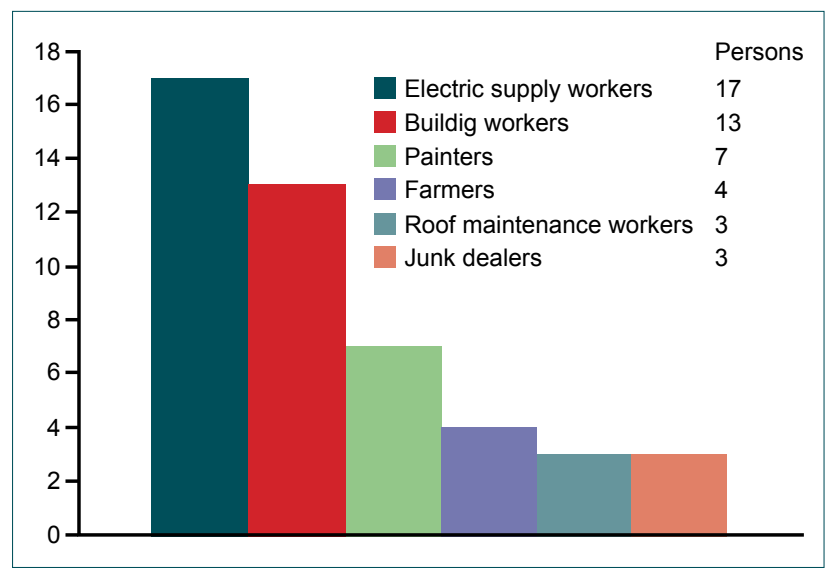

Figure 2. Occupational distribution of patients with electrical injuries sustained in industrial accidents.

attempted suicide $(n=1)$, and others $(n=8)$. Patients who sustained industrial injuries were electricity supply workers $(n=17)$, construction workers $(n=13)$, painters $(n=7)$, farmers $(n=4)$, roof maintenance workers $(n=3)$, and junk dealers $(n=3)$ (Figure 2). Four patients $(4.2 \%)$ died during the study period. Of these patients, 3 died of acute renal failure, and I died of sepsis and multiple organ failure.

Injuries were classified as low-voltage burns ( $n=42 ; 44.7 \%$ ), high-voltage burns $(n=47 ; 50 \%)$, or flash burns caused by lightning $(n=5 ; 5.3 \%)$. Minimum burned TBSA was $2 \%$ for low-voltage burns, $7 \%$ for high-voltage burns, and $5 \%$ for flash burns. Maximum burned TBSA was $20 \%$ for low-voltage burns, $80 \%$ for high-voltage burns, and $70 \%$ for flash burns. Mean burned TBSA was $11.9 \pm 6.9 \%, 21.8 \pm 19.8 \%$, and $23.4 \pm 26.3 \%$ per classification, respectively.

Length of hospital stay was 2-30 days (with a mean of 8.6 \pm 6.2 days) for low-voltage burns. Patients with high-voltage burns were admitted for 3-116 days (with a mean of $21.3 \pm 19.8$ days). Patients with flash burns were admitted for 4-20 days (with a mean $13.2 \pm 14.6$ days). 
Two patients had coexisting epilepsy, I of whom had mental retardation and made contact with an electrical wire with the intention of committing suicide. This patient had seconddegree skin burn over $12 \%$ of TBSA and spent 8 days in admission. Following treatment he was discharged, without the need for surgical intervention. The other epileptic patient was an II-year-old male with $2^{\text {nd }}$ - and $3^{\text {rd }}$-degree burns over $15 \%$ of TBSA. The patient required debridement and grafting before being discharged on the $16^{\text {th }}$ day of admission. Two patients had gastric ulcer, only I of whom had undergone surgical treatment. A female patient in the sixth month of pregnancy was hospitalized for 2 days and discharged after an uneventful course of treatment. During the follow-up period, no complication was observed in the mother or fetus. Two patients had coronary artery disease, and treatment was uneventfully completed.

Seven patients $(7.4 \%)$ presented with trauma accompanying the electrical injury, all of which were caused by falls from height. These patients had sustained high-voltage electrical injury. Accompanying trauma was intracranial injury in 2 patients, soft tissue injury in 2 , bone fracture in 2 , and intraabdominal injury in I patient.

Findings suggestive of infection (fever, hypotension, hypo- or hyperglycemia, or alterations in mental state) were observed in 31 patients (32.9\%). Culture results identified 10 bacterial types, with 19 subtypes. Empirical antimicrobial treatment was initiated immediately, followed by drug replacement based on culture results, as necessary. Positive cultures grew mainly gram-negative cocci, primarily enterobacteriaceae, followed by gram-positive cocci, predominantly staphylococci and enterococci. Microorganisms identified were Staphylococcus spp. $(\mathrm{n}=16)$, Acinetobacter spp. $(\mathrm{n}=1 \mathrm{l})$, Pseudomonas spp. $(\mathrm{n}=\mid \mathrm{I})$, Enterococcus spp. $(\mathrm{n}=5)$, Escherichia coli $(\mathrm{n}=3)$, Enterobacter spp. $(\mathrm{n}=2)$, Klebsiella spp. $(\mathrm{n}=2)$, Pantoea spp. $(n=2)$, Proteus spp. $(n=I)$, and Serratia spp. $(n=I)$ (Figure 3).

Upper extremities were found to be more frequently injured than lower extremities. Injury sites were: the right upper extremity (in 58 patients), left upper extremity (in 47), right lower extremity (in 39), left lower extremity (in 28), thoracic wall (in 22), posterior trunk (in 18), abdomen (in 15), face (in I2), neck (in 7), and the genital region (in 4) (Figure 4).

During the early phase of management, 35 patients $(37 \%)$ required surgical wound debridement, 24 of whom required 2 or more additional debridements. Reconstruction with skin graft was performed in 32 patients, while 9 patients required the use of various flaps to cover wounds. Eight patients underwent amputation during the early phase. Fasciotomy was performed in 3 cases of suspected compartment syndrome. Z-plasty was performed in 3 patients, all of whom required surgical revision due to skin graft complication. Tenolysis was performed in I patient, and surgical revision was performed to treat scar formation in I patient.

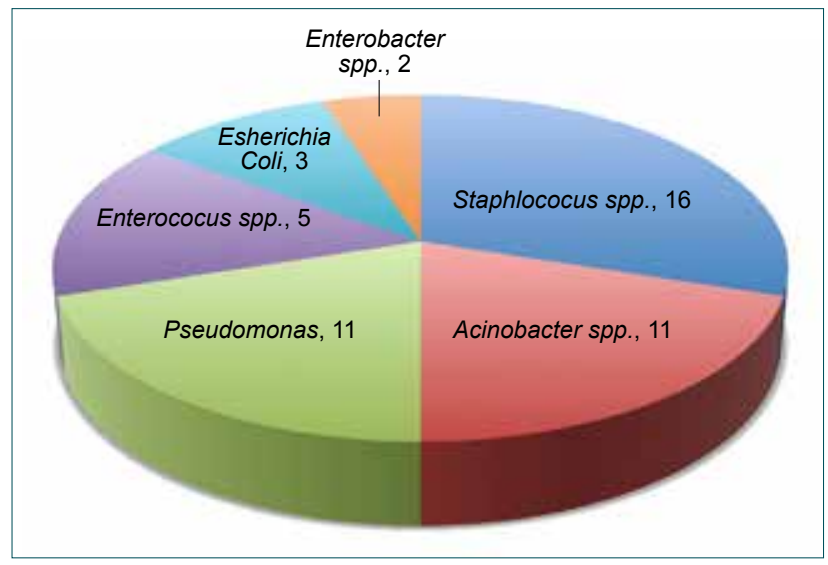

Figure 3. Isolated microorganisms.

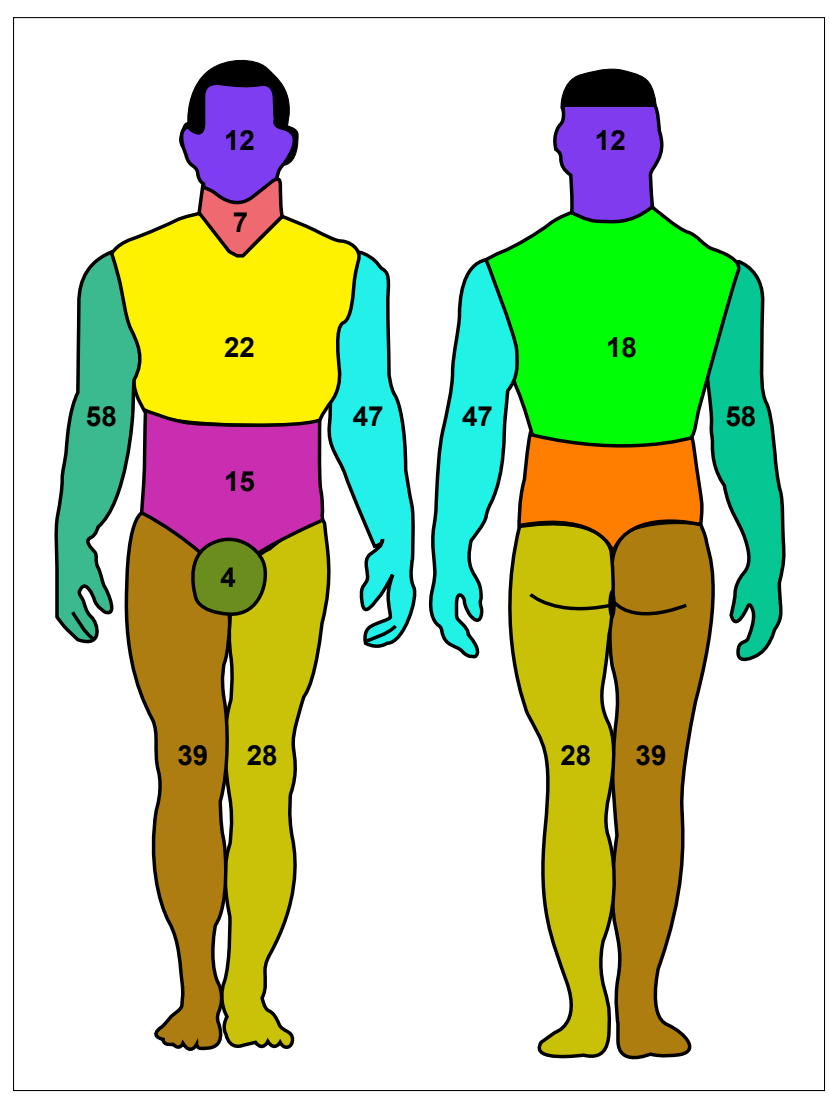

Figure 4. Regional distribution of electrical burns.

Average cost per patient was I,208.55 TL in cases of lowvoltage electrical burns, and average cost per hospital day was 139.23 TL. Average cost per patient with high-voltage burn injury was 4,765. $13 \mathrm{TL}$, and per day cost was 224.44 TL.

\section{DISCUSSION}

Electrical burns, the result of exposure to supraphysiologic electric currents, are among the most devastating tissue injuries. Electrical burns occur less frequently than scald or flame burns, but have higher associated rates of mortality and morbidity, particularly in cases of high voltage. The mechanism of tissue damage is generally related to puncture 
and denaturation of cell membranes caused by the direct electrical forces.

Electrical burns are more frequently sustained in Turkey, compared to the global average.[II] They are most frequently sustained by young male adults in industrial accidents. Al et al. reported that $76.4 \%$ of electric burns are sustained by adult males, $23.6 \%$ by females.[II] Haberal et al. similarly reported that $82 \%$ of electric burns are sustained by adult males and $18 \%$ by females.[12] In the present study, $89 \%$ of patients were male, II\% female, and results were comparable with the literature with a plethora of male subjects.

In a study performed in Turkey, the authors reported that rates of the high- and low-voltage electricity burns were $54.5 \%$ and $45.5 \%$, respectively. ${ }^{[13]}$ Similarly, the rate of highvoltage burns in the present study was $50 \%$, and the rate of low-voltage burns $44.7 \%$ (while the rate of flash burns was $5.3 \%$ ). High-voltage electricity burns cause more serious tissue damage due to the high amounts of energy exerted. ${ }^{[14,15]}$

Mean patient age was reported as 30.2 or 25 years in a majority of studies. ${ }^{[13,16,17]}$ Mean age in the present study was 18.8 years in females and 27.4 years in males. It was presently determined that mean TBSA was $11.9 \%$ in cases of low-voltage burns, and $21.8 \%$ in those of high voltage. It was also found that these burns are most commonly sustained by young male adults, and can lead to significant loss in employment. ${ }^{[1,3,6,7,10]}$

Hospitalization was longer for patients with high-voltage burns. Duration of hospital stay for patients with low-voltage and high-voltage burns was presently determined as $8.6 \pm 6.2$ days and $21.3 \pm 19.8$ days, respectively. Greater energy is expended in high-voltage burns, and tissues are more deeply penetrated, creating wider burn surface areas, and resulting in longer periods of hospitalization and higher treatment costs.

Cancio et al. reported that $25 \%$ of electricity burns accompanied by traumas were caused by falls from heights. ${ }^{[18]}$ In the present study, 7 patients $(7.4 \%)$ sustained concomitant trauma in this way, a rate lower than that reported. Patients may have been primarily treated for their otherwise lifethreatening conditions elsewhere before they were referred to the present burn center, accounting for the low rate.

Hammond et al. reported that $3 \%$ of electricity burns caused death. ${ }^{[19]}$ The rate in Turkey has been reported as $4.7 \%$. The present rate of mortality was $4.25 \%$. While the most frequently reported cause of electrical burn-related mortality was sepsis, 3 patients in the present study died from acute renal failure, and I patient died from sepsis. ${ }^{[20]}$ This discrepancy may be attributed to either inadequate hydration at the early stages prior to referral or delay in referral to emergency services. Attempted suicide is a rare cause of electricity burn. [21,22] However, in the present study, I patient with epilepsy and mental retardation attempted suicide by electric shock.
Wound infections and complications frequently accompany electrical burns. Estahbanati et al. reported that the agents that most commonly caused these infections were Pseudomonas aeruginosa (57\%), Acinetobacter spp. (17\%), Escherichia coli (12\%) and Staphylococcus aureus (8\%). ${ }^{[23]}$ In the present study, Staphylococcus spp. $(n=16)$, Acinetobacter spp. $(\mathrm{n}=\mathrm{II})$, Pseudomonas spp. $(\mathrm{n}=\mathrm{II})$, Enterococcus spp. $(\mathrm{n}=5)$, Escherichia coli $(\mathrm{n}=3)$, Enterobacter spp. $(\mathrm{n}=2)$, Klebsiella spp. $(\mathrm{n}=2)$, Pantoea spp. $(\mathrm{n}=2)$, Proteus spp. $(\mathrm{n}=\mathrm{l})$, and Serratia spp. $(n=l)$ were grown from cultures. It has been emphasized that local and intravenous antibiotics designed to target a specific agent are essential in the treatment of wound infection and sepsis. The most common cause of death in the present study was acute renal failure, though sepsis is the most frequently reported cause of electrical burn-related mortality. Consequently, it should be noted that intravenous fluid resuscitation and close observation of patients is essential in the treatment of burn injury.

Cost is another factor in the treatment of electrical burn injuries. Cases of high-voltage injury were found to incur costs more than twice as high as those of low-voltage injury. Average total cost per patient was I,208.55 TL in cases of lowvoltage electrical burns, and average cost per hospital day was 1 39.23 TL. Medical costs of the 46 patients with high-voltage electrical burns ranged from I 20.89 TL to I5,033.00 TL. Total medical cost per high-voltage burn patient averaged 4,765. I3 TL, and average cost per day was $224.44 \mathrm{TL}$. It is believed that these high costs can be attributed to longer hospital stays, higher number of surgical procedures, and more extensive surgeries required by patients with high-voltage electrical injuries.

In conclusion, although treatment modalities have evolved and awareness among the public has increased, electrical burn injuries still cause significant mid- and long-term morbidity. Increasing awareness of electrical safety, the construction of safer electrical distribution networks, and the implementation of more effective means of occupational safety may serve to reduce the number of these devastating and occasionally fatal injuries.

Acknowledgement: This study was presented as a poster at the $34^{\text {th }}$ National Congress of Turkish Society of Plastic Reconstructive and Aesthetic Surgeons. The authors would thank Dr. Umut Tuncel for his assistance in preparing this manuscript.

Conflict of interest: None declared.

\section{REFERENCES}

1. Haddad SY. Electrical burn - a four-year study. Ann Burns Fire Disasters 2008;21:78-80.

2. Iqbal T, Saaiq M, Ali Z. Epidemiology and outcome of burns: early experience at the country's first national burns centre. Burns 2013;39:358-62. 
3. Aldemir M, Kara IH, Girgin S, Güloglu C. Factors affecting mortality and epidemiological data in patients hospitalised with burns in Diyarbakir, Turkey. S Afr J Surg 2005;43:159-62.

4. Liu Y, Cen Y, Chen JJ, Xu XW, Liu XX. Characteristics of paediatric burns in Sichuan province: epidemiology and prevention. Burns 2012;38:26-31. Crossref

5. Liu Y, Chen JJ, Crook N, Yu R, Xu XW, Cen Y. Epidemiologic investigation of burns in the elderly in Sichuan Province. Burns 2013;39:389-94.

6. Luz DP, Millan LS, Alessi MS, Uguetto WF, Paggiaro A, Gomez DS, et al. Electrical burns: a retrospective analysis across a 5-year period. Burns 2009;35:1015-9. Crossref

7. Sun CF, Lv XX, Li YJ, Li WZ, Jiang L, Li J, et al. Epidemiological studies of electrical injuries in Shaanxi province of China: a retrospective report of 383 cases. Burns 2012;38:568-72. Crossref

8. Kim HD, Hwang SM, Lim KR, Jung YH, Ahn SM, Song JK. Toe Tissue Transfer for Reconstruction of Damaged Digits due to Electrical Burns. Arch Plast Surg 2012;39:138-42. Crossref

9. Singerman J, Gomez M, Fish JS. Long-term sequelae of low-voltage electrical injury. J Burn Care Res 2008;29:773-7. Crossref

10. Vierhapper MF, Lumenta DB, Beck H, Keck M, Kamolz LP, Frey M. Electrical injury: a long-term analysis with review of regional differences. Ann Plast Surg 2011;66:43-6. Crossref

11. Al B, Aldemir M, Güloğlu C, Kara IH, Girgin S. Epidemiological characteristics of electrical injuries of patients applied to the emergency department. [Article in Turkish] Ulus Travma Acil Cerrahi Derg 2006;12:13542.

12. Haberal $M, U$ çar $N$, Bilgin $N$. Epidemiological survey of burns treated in Ankara, Turkey and desirable burn-prevention strategies. Burns 1995;21:601-6. Crossref
13. Karadaş S, Gönüllü H, Oncü MR, Işık D, Canbaz Y. The effects on complications and myopathy of different voltages in electrical injuries. [Article in Turkish] Ulus Travma Acil Cerrahi Derg 2011;17:349-53. Crossref

14. ten Duis HJ. Acute electrical burns. Semin Neurol 1995;15:381-6.

15. Cooper MA. Emergent care of lightning and electrical injuries. Semin Neurol 1995;15:268-78. Crossref

16. Kopp J, Loos B, Spilker G, Horch RE. Correlation between serum creatinine kinase levels and extent of muscle damage in electrical burns. Burns 2004;30:680-3. Crossref

17. Blackwell N, Hayllar J. A three year prospective audit of 212 presentations to the emergency department after electrical injury with a management protocol. Postgrad Med J 2002;78:283-5. Crossref

18. Cancio LC, Jimenez-Reyna JF, Barillo DJ, Walker SC, McManus AT, Vaughan GM. One hundred ninety-five cases of high-voltage electric injury. J Burn Care Rehabil 2005;26:331-40. Crossref

19. Hammond JS, Ward CG. High-voltage electrical injuries: management and outcome of 60 cases. South Med J 1988;81:1351-2. Crossref

20. Kurtoğlu M, Alimoğlu O, Ertekin C, Güloğlu R, Taviloğlu K. Evaluation of severe burns managed in intensive care unit. [Article in Turkish] Ulus Travma Acil Cerrahi Derg 2003;9:34-6.

21. İnce $\mathrm{CH}$, Fincancı ŞK, Arıcan M, Akkay E. Elektrikle intihar: bir olgu bildirisi. 1. Adli Bilimler Kongresi (12-15 Nisan) Kongre Kitabı. Adana 1994. p. 342-3.

22. Byard RW, Hanson KA, Gilbert JD, James RA, Nadeau J, Blackbourne $B$, et al. Death due to electrocution in childhood and early adolescence. J Paediatr Child Health 2003;39:46-8. Crossref

23. Estahbanati HK, Kashani PP, Ghanaatpisheh F. Frequency of Pseudomonas aeruginosa serotypes in burn wound infections and their resistance to antibiotics. Burns 2002;28:340-8. Crossref

\section{ORİJINAL ÇALIŞMA - ÖZET}

\section{Elektrik yanıkları: Beş yıllık geriye dönük değerlendirme}

\section{Dr. Alper Kurt,, Dr. Kamil Yıldırım, ${ }^{1}$ Dr. Çağlayan Yağmur, ${ }^{3}$ Dr. Osman Kelahmetoğlu, ${ }^{2}$ Dr. Ozan Aslan, ${ }^{1}$ Dr. Murat Gümüş, ${ }^{1}$ Dr. Ethem Güneren ${ }^{2}$}

\footnotetext{
1Samsun Eğitim ve Araştırma Hastanesi, Plastik Rekonstrüktif ve Estetik Cerrahi Kliniği, Samsun

${ }^{2}$ Bezm-i Alem Vakıf Üniversitesi Tıp Fakültesi, Plastik Rekonstrüktif ve Estetik Cerrahi Anabilim Dalı, İstanbul

${ }^{3}$ Ondokuz Mayıs Üniversitesi Tıp Fakültesi, Plastik Rekonstrüktif ve Estetik Cerrahi, Samsun
}

AMAÇ: Elektrik yanığı; haşlanma ve alev yanıklarından sonraki en sık üçüncü yanık şeklidir. Tedavi olanaklarındaki gelişmeler sayesinde düşme görülen mortalite oranlarına rağmen elektrik yanıkları halen ciddi komplikasyonlara ve sosyoekonomik sonuçlara neden olan yaralanmalardır. Bu çalışmada 2008-20I 2 yılları arasında Samsun Eğitim Araştırma Hastanesi Yanık Merkezi'nde yatarak tedavi gören hastalara ait verilerin geriye dönük analizi sunuldu.

GEREÇ VE YÖNTEM: 2008-20I2 yılları arasında elektrik yanığı ile yatıılan ve gerekli tedaviler uygulanan toplam 94 (84 erkek, 10 kadın) hasta incelendi. Hasta demografik bilgileri, yanık derecesi, toplam alanı, voltaj türü (yüksek/alçak), tedavi maliyeti, tedavi yöntemleri, enfeksiyon oranları ve eşlik eden travmalar açısından değerlendirildi.

BULGULAR: Hastalarda ortalama yaş $26.4 \pm 13.2$ olarak bulundu, 47 hastada (\%50) yüksek voltaj yanığı, 42 hasta düşük voltaj yanığı ve beş hasta ark yanığı mevcuttu. Toplam yanık alanı yüksek voltajda \%2।.8 ( \pm 19.8), düşük voltajda \%। I.9 ( \pm 6.9 ) olarak bulundu. Yedi hastada eşlik eden travma mevcuttu. Otuz bir hastada (\%32.9) enfeksiyon bulguları gelişti ve uygun tedavi başlandı. Yüksek voltaj ve düşük voltaj yaralanmalarının toplam hastanede kalma ve tedavi maliyetleri arasında anlamlı fark mevcuttu.

TARTIŞMA: Yaptığımız geriye dönük araştırmada yüksek voltaj yaralanmalarının büyük çoğunluğunu sanayi yaralanmaları olduğunu ve olguların tümünün genç erkek yetişkinlerden oluştuğunu gözlemledik. Çalışanların iş güvenliklerinin artırılmasını sağlayan önlemlerin yanı sıra elektrik dağııı şebekelerinin güvenliğinin pekiştirilmesi ve elektrik kullanımı konusundaki güvenlik bilincinin artıııması bu önemli yaralanmaların sıklığını ve şiddetini azaltacaktır.

Anahtar sözcükler: Analiz; elektrik yanıkları, geriye dönük.

Ulus Travma Acil Cerrahi Derg 2016;22(3):278-282 doi: 10.5505/tjtes.20 I5.5549| 